\title{
Development of insulator curtains for the restriction of extreme cold and fog
}

\author{
Sugeet Sethi ${ }^{1}$, Dr Savita Verma ${ }^{2}$ \\ ${ }^{1}$ P.hD - Chemistry, Madhyanchal Professional University, Bhopal, M.P \\ ${ }^{2}$ Assistant Professor -Chemistry, Madhyanchal Professional University, Bhopal, M.P
}

\begin{abstract}
Extreme cold weather in winter days and winter nights is very serious problem for those homes and buildings in which outside walls becomes too much cold due to the conduction of coldness and cold breeze. In foreign countries trend of construction of green buildings is very common but when we are talking about the developing countries like Nepal, Bhutan, India and Sri-Lanka homes and buildings are being constructed according to affordability. So, it's a problem of many traditional and common houses. It becomes very difficult to live/ survive in such weather conditions where the room temperature becomes less than $18{ }^{\circ} \mathrm{C}$ in days and less than $10{ }^{\circ} \mathrm{C}$ in winter nights.

The solution for such type of serious problem exists in the invention of such composite insulator materials for making curtains/ curtain pads and window insulator covers to avoid the entry of cold breeze and fog in our homes which will add comfort in living during these days.
\end{abstract}

Keywords: Layering effect, vertical band effect, window covers, cold wave, insulation.

\section{INTRODUCTION:-}

The problem of extreme cold is not the present time problem instead it's an issue of thousands of years back in the past everywhere. sometimes extreme cold breeze flows in some states or specific geographic area along with appearance of too much fog and mist in the morning time such type of climatic conditions adversely affect the human health, Aquatic life, wild life etc. When we are talking about its adverse effect on the human health then we can say that by the cooling of body parts leads to frostnip,frostbite (freezing injuries), immersion foot and hypothermia (non-freezing injuries).Among non-freezing injuries hypothermia is most serious one. The arrival of cold wave in the Madhya Pradesh and some other states which results into drop of $4-5{ }^{0} \mathrm{C}$ in various districts like Bhopal,Ujjain,Indore, Seoni,Chhatarpur,Sagar,Datia and Gwalior (weather report obtained from India Meteorological Department's Bhopal office.) in the last month of December 2021. Due to Cold wave the normal room temperature decreases very rapidly and it was reported $4^{0} \mathrm{C}$ in Datia and Gwalior. The problem of extreme cold originates from arrival of cold breeze from north east of our country which is also called as cold wave.

In order to prevent from the adverse effect of extreme cold we can use and install some insulator curtain pads and window insulation covers on our windows and ventilation.Jute,cotton and wool are very good insulators of heat among organic category whereas polystyrene foam, polystyrene and Khaadi cloths are having very good thermal insulation properties as a man made products.

\section{EXPERIMENTAL METHODS OR METHODOLOGY}

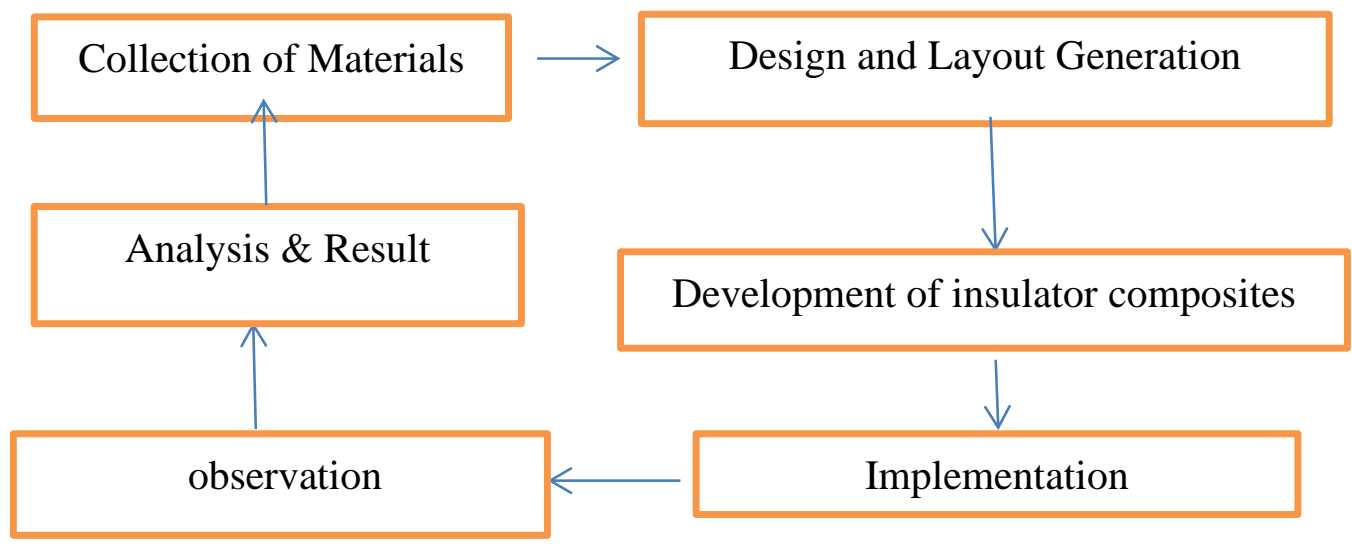




\section{International Advanced Research Journal in Science, Engineering and Technology \\ Impact Factor $7.105 \div$ Vol. 9, Issue 1, January 2022 \\ DOI: 10.17148/IARJSET.2022.9155}

Methodology of my research work is a systematic step by step process which includes many important steps. These steps are as follows:-

Collection of Materials-Insulator materials used: Insulator material used are padded cotton or clean used cotton pads, used woollens, Khaadi cloth or used Khaadi bed sheet, used packaging cartoon, polystyrene boards as rigid expanded boards, Polystyrene Foam sheets, Jute fibers,used egg trays. Other materials:-Epoxy foam adhesive, cello tape, Thread and needle, Polystyrene board pins. Equipments:- Infra red Thermometer with Laser sensor, Room temperature thermometer.

Design:-In my Research work ,i have developed two insulator composites.(i)Insulator Curtains or Cold Insulator curtain Pads (CICP) (ii)Window Insulation Covers (WIC's).

Development of composite insulator- I developed my models by the use of layering method and vertical bands of hard board as in case of insulator curtain.

Layering effect: If we make an Insulator composite to resist cold by different layers of different insulator materials then we observed that the inner most layer of insulation material has the lowest thermal conduction capacity..

Band effect of hard insulator material: - In the development of cold Insulator curtain pads (CICP) I have added vertical bands made of hard board or used packaging cartoon in order to break the continuity of incident cold air on the composite surface. These bands play a role of coldness barrier in the spreading of cool air.

Implementation part:- Implementation of these models have been done by the installation and fixing of such models into our home windows.

1) insulator curtain :- by cloth picker

2) Window insulator cover:- by tie up with ropes to grills of the windows.

Observation \& Analysis:--After the successful installation of these insulator composite models in the windows I have taken readings of temperature outside and inside the rooms of house after an equal interval of 3 days for one month.

\section{RESULTS AND DISCUSSION}

As the insulator composites are made according to layering effect of insulation materials and vertical band effect of hard insulation material hence both are very effect in prevention of falling of temperature during extreme cold days and foggy days..

a)

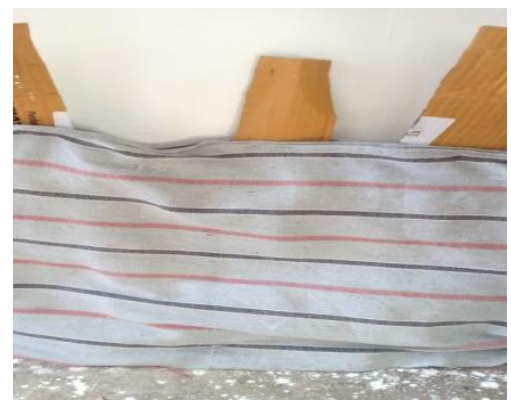

b)

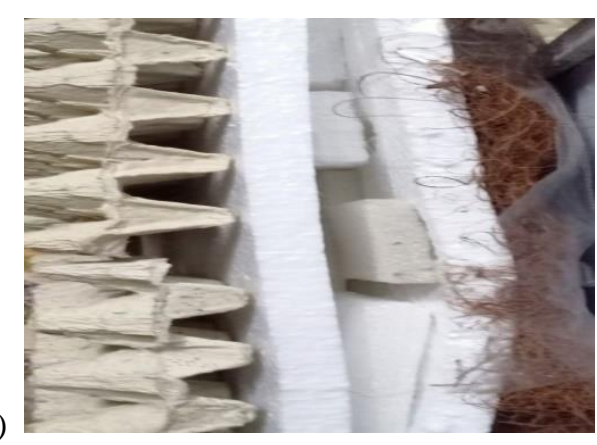

Image-a showing curtain insulator and image b showing window insulator cover.

\begin{tabular}{|l|}
\hline Used blanket piece $2 \mathrm{~mm}$ \\
\hline Wool $2 \mathrm{~mm}$ \\
\hline Bands of hard board \\
$3 \mathrm{~mm}$ thickness \\
\hline Wool $2 \mathrm{~mm}$ \\
\hline Khaadi $1 \mathrm{~mm}$ \\
\hline
\end{tabular}

\begin{tabular}{|l|}
\hline USED EGG TRAYS Layer-1 thickness 1.5 inch \\
\hline Polystyrene board Layer 2 thickness $1.5 \mathrm{cms}$ \\
\hline Polystyrene foam Layer3 thickness $1 \mathrm{~cm}$ \\
\hline Polystyrene board Layer $4 \quad$ thickness $1.5 \mathrm{~cm}$ \\
\hline Jute and lamination Layer 5 thickness 1.5 inch \\
\hline
\end{tabular}




\section{International Advanced Research Journal in Science, Engineering and Technology \\ Impact Factor 7.105 Vol. 9, Issue 1, January 2022 \\ DOI: 10.17148/IARJSET.2022.9155}

Table-1 (a) showing layers in curtain insulator \& (b) showing window cover.

\begin{tabular}{|c|c|c|}
\hline Date of recording & Temperature outside home & Temperature of room \\
\hline $22 / 12 / 2021$ & $11.0^{0} \mathrm{C}$ & $15.2^{0} \mathrm{C}$ \\
\hline $25 / 12 / 2021$ & $10.5^{0} \mathrm{C}$ & $15.0^{0} \mathrm{C}$ \\
\hline $28 / 12 / 2021$ & $12.0^{0} \mathrm{C}$ & $17.2{ }^{0} \mathrm{C}$ \\
\hline $31 / 12 / 2021$ & $11.5^{\circ} \mathrm{C}$ & $16.2{ }^{0} \mathrm{C}$ \\
\hline $03 / 01 / 2022$ & $13.0^{0} \mathrm{C}$ & $17.5^{0} \mathrm{C}$ \\
\hline $06 / 01 / 2022$ & $13.8{ }^{0} \mathrm{C}$ & $17.8^{0} \mathrm{C}$ \\
\hline $09 / 01 / 2022$ & $12.3^{\circ} \mathrm{C}$ & $16.5^{0} \mathrm{C}$ \\
\hline $15 / 01 / 2022$ & $12.7^{0} \mathrm{C}$ & $17.1{ }^{0} \mathrm{C}$ \\
\hline $18 / 01 / 2022$ & $12.9^{0} \mathrm{C}$ & $17.5^{\circ} \mathrm{C}$ \\
\hline $21 / 01 / 2022$ & $11.9^{\circ} \mathrm{C}$ & $16.5^{\circ} \mathrm{C}$ \\
\hline
\end{tabular}

Table 2 showing performance of curtain insulator(CICP), $\mathrm{x}$ axis-dates, y axis -temperature values

For taking readings I have used IR thermometer compatible with laser sensor to take the temperature readings of outside the window and inside the window (room).

Analysis:- Insulator curtains or cold insulator curtain pads obstructs the cold efficiently by its layering effect of adjacent insulator materials and Vertical band effect of hard board bands which helps in discontinuity of flow of air uniformly on the surface of composite. This composite if we apply on all the windows and ventilation of room then it prevents the room temperature from fall down and approximately it maintains temperature higher than outside $3-4{ }^{\circ} \mathrm{C}$.

\begin{tabular}{|l|l|l|}
\hline Date of recording & Temperature outside home & Temperature of room \\
\hline $28 / 12 / 2021$ & $12.6{ }^{0} \mathrm{C}$ & $16.2^{0} \mathrm{C}$ \\
\hline $30 / 12 / 2021$ & $11.8^{0} \mathrm{C}$ & $15.6^{0} \mathrm{C}$ \\
\hline $02 / 01 / 2022$ & $12.5^{0} \mathrm{C}$ & $16.1^{0} \mathrm{C}$ \\
\hline $05 / 01 / 2022$ & $13.1^{0} \mathrm{C}$ & $16.4^{0} \mathrm{C}$ \\
\hline $08 / 01 / 2022$ & $12.1{ }^{0} \mathrm{C}$ & $16.5{ }^{0} \mathrm{C}$ \\
\hline $11 / 01 / 2022$ & $13.2{ }^{0} \mathrm{C}$ & $15.8^{0} \mathrm{C}$ \\
\hline $14 / / 01 / 2022$ & $12.5^{0} \mathrm{C}$ & $17.5^{\circ} \mathrm{C}$ \\
\hline $17 / 01 / 2022$ & $12.7{ }^{0} \mathrm{C}$ & $18.1^{0} \mathrm{C}$ \\
\hline $20 / 01 / 2022$ & $12.1^{0} \mathrm{C}$ & $17.5^{0} \mathrm{C}$ \\
\hline
\end{tabular}

Table 3 showing maintenance of room temperature in ${ }^{0} \mathrm{C}$ by window insulator covers.

Data Analysis:- Window insulator covers obstructs the cold efficiently by its layering effect of adjacent insulator materials and Air insulation effect of hard board based used egg trays which helps in filling of air uniformly in its exposed surface on outside the room. This composite if we apply on all the windows and ventilation of room in winter season then it prevents the room temperature from its falling and approximately it maintains temperature higher than outside in the range of 3.3 to $5.4{ }^{\circ} \mathrm{C}$..

\section{CONCLUSION}

Insulator composite designing is vast field of development of thermal composite insulator materials and models in the field of green chemistry and Energy savings of buildings. In the result part I found that the energy saving efficiency or temperature maintenance capacity of window insulator covers is better than insulator curtains. As windows covers maintains temperature higher than outside upto higher limit of $5.4{ }^{\circ} \mathrm{C}$.

\section{REFERERNCES:-}

(1) Sanjoy Debnath,Thermal Insulation Material Based on "Jute",http:/dx,doi.org/10.5772/ 63223

(2) Hyung-Kweon kim, Geum-choon kang,Jong-Pil Moon, Tae-Seok Lee \& Sung-Sik Oh. "Estimation of Thermal performance \& heat loss in plastic Green houses with and without thermal curtains ", journal.Energies, vol no11,578, pp-1-5, 2018

(3) Richard Fitton,Will Swan, Tara Hughes,Moaad Benjaber,'The thermal performance of window coverings in a whole house test facility with single glazed sash windows" Energy Effiency,open access doi 10.1007/s12053-0179529-0,pp-1-5,9.

(4) Baker P, Research into the thermal performance of traditional walls:solid brick walls Portsmouth:Historic England,pp-5-17,2013. 


\section{International Advanced Research Journal in Science, Engineering and Technology \\ Impact Factor $7.105 \div$ Vol. 9, Issue 1, January 2022 \\ DOI: 10.17148/IARJSET.2022.9155}

(5) O.M Alifanov, A.V. Nenarokomov,V.m. Gonzalez,"study of Multi layer Thermal insulation by inverse problems method,Acta Astronautica 65,pp-1287-1290.2009.

(6) Zhaoyun Zeng,Godfried Augenbroe,'Movable window insulation as an instantiation of the adaptive building envelope:An investigation of its cost-effectiveness in the U.S,Energy and Buildings,Volume 247,pp- 10-15,2021.

(7) Nicol K,'The thermal effectiveness of various types of window coverings,Energy and Buildings,doi:10.1016/03787788(86)90023-x,pp-230-235,1986

(8) Lunde,H. A.,\& Lindley,J.A,"effects of window treatments in cold climates" Home Economics Research journal,doi:10.1177/1077727X8801600307,pp-222-230.,1988.

(9) May,N \& Sanders,C,’Moisture risk assessment \& Guidance ’London:STBA,pp-25-29,2014

(10) Hens,H,Building Physics-heat,air and moisture:fundamentals and engineering methods with examples and exercises,edition-2 ${ }^{\text {nd }}$,NEW YORK:Wiley ISBN:978-3-43-03027-1.

(11) Woodson,E.M,Horridge,P,\& Khan,S,Interior insulators:problem solvers at the window, ASHRAE Transactions92(1A), 439-452.

(12)Fang.X,"A study of the U -factor of a window with a cloth curtain".Applied thermal Engineering ,21(5),doi:10.1016/S1359-4311(00)00071-5,pp-549-554.

(13) Feather,B.L "Window treatments and energy conservation",journal of Interior design, doi:10.1016/S13594311(00)00071-5, pp6(2),43-45

(14) V.R.Gordon,R. Holness,'Improvingenergy efficiencyin existing buildings”,ASHRAE journal ,vol.50,pp-1220,2008

(15) M.A Medina,"On the performance of radiant barriers in combination with different attic insulation levels,Energy and Buildings,volume-33,pp-31-41,2000. 